\author{
M. Shnarbekova \\ Al-Farabi Kazakh National University, Kazakhstan, Almaty, e-mail: meru_12_12@mail.ru
}

\title{
MODERN PRACTICES OF OBTAINING HIGHER EDUCATION IN KAZAKHSTAN
}

This article is devoted to the analysis of social practices in the field of higher education, formed in post-Soviet Central Asian countries, with specific references to Kazakhstan. Kazakhstan was significantly affected by the collapse of the Soviet system: breaking ties with many leading former Soviet universities entailed irreversible processes in changing of the entire infrastructure of higher education in the country. Last decades to take place the process of reduction of middle level education and closure of vocational colleges. These has caused a sharp transition of school graduates to higher education unit, thereby increasing its demand. New opportunities allow studying as well as undergoing internships abroad, tuition fee free education based on the state grant. But there is a differentiation in access to quality higher education and increase of economic barriers to obtain it for children from lower-income families. These differences in access contributed to the formation of «elite» and «mass» universities in the educational space of Kazakhstan and the concentration of youth from lower-income families in non-prestigious educational institutions with low tuition fee. Thereby there is a risk that such situation can increase influence of social background on labour market outcomes (salary and occupational status). In the article the significance of the economic capital in the market of higher education and the social consequences of the choice of "affordable" vocational education are analyzed.

Key words: higher education, access to education, economic barriers, high-income families, lower income families, family resource potential.

\section{М.К. Шнарбекова}

Ә^-Фараби атындағы Қазақ, ұлттық университеті, Қазақстан, Алматы қ., e-mail: meru_12_12@mail.ru

\section{Қазақстанда жоғары білім алудың қазіргі тәжірибесі}

Аталмыш мақала пост-кеңестік елдердің, соның ішінде Қазақстанның білім беру саласында қалыптасқан ахуалды талдауға бағытталған. Кеңестік жүйенің құлауы Қазақстанға елеулі ықпал етті: жетекші пост-кеңестік жоғары оқу орындарымен көптеген байланыстардың тоқтауы жоғары мектеп инфраструктурасының толық өзгеруіне әкелді. Кейінгі онжылдықта арнайы орта білім беру деңгейінің қысқаруы мен кәсіби-техникалық училищелердің жабылуы мектеп түлектерінің білім берудің жоғары деңгейіне тікелей өтүіне әсер етті және сәйкесінше жоғары білімге деген сұранысты арттырды. Қазіргі кезде жаңа мүмкіндіктер шетелде білім алуға, ғылыми тағылымды өтуге, мемлекеттік грант негізінде ақысыз білім алуға мүмкіндік береді. Аегенмен, сапалы білім алуда дифференциация кездеседі және әлеуметтік әлсіз топқа жататын жастар үшін экономикалық келергінің артуы байқалады. Қолжетімділіктегі мұндай айырмашылық білім беру кеңістігінде «элиталық» және «қолжетімді» университеттердің қалыптасуына және беделі жоғары емес университетте табыс деңгейі төмен отбасыдан шыққан жастар үлесінің артуына әкеледі. Мұндай жағдай перспективада әлеуметтікэкономикалық жағдайдың еңбек нарығында кәсіби жетістікке жету мүмкіндігіне, соның ішінде табыс пен кәсіби мәртебеге ықпалының артуына әсер етеді. Мақа^ада жоғары білім алуда экономикалық капиталдың маңыздылығы мен "қолжетімді» кәсіби таңдаудың әлеуметтік салдарлары сараланады.

Түйін сөздер: жоғары білім, білім қолжетімділігі, экономикалық барьер, табысы жоғары отбасылар, табысы төмен отбасылар, отбасының ресурстық потенциалы.

\section{М.К. Шнарбекова}

Казахский национальный университет им. аль-Фараби, Казахстан, г. А^маты, e-mail: meru_12_12@mail.ru

\section{Современные практики получения высшего образования в Казахстане}

Аанная статья посвящена анализу социальных практик в сфере высшего образования, сложившихся в постсоветский период в странах Центра^ьной Азии, в частности в Казахстане. 
РаспаА советской системы существенно повлиял на Казахстан: разрыв многочисленных связей с ведущими бывшими советскими вузами повлек за собой необратимые процессы в изменении всей инфраструктуры высшей школы страны. В последнее десятилетие прослеживается сокращение системы среднего звена обучения и закрытие профессионально-технических училищ, что обусловило резкий переход выпускников школ в высшее звено обучения, тем самым увеличив его спрос. Сейчас новые возможности позволяют обучаться за рубежом, проходить зарубежную стажировку, обучаться бесплатно на основе государственного гранта. ОАнако, наблюдается Аифференциация в доступности качественного высшего образования и увеличение экономических барьеров его получения Аля молодежи из соцально непривелигированных семей. Такие различия в доступности ведут к формированию "элитных» и "дешевых» университетов в образовательном пространстве и концентрации молодежи из семей с низким уровнем дохода в непрестижных высших учебных заведениях. Такая тенденция порожАает риск увеличения роли социально-экономического статуса семьи в достижении молодежью профессиональных успехов (высокий доход, карьерный рост) на рынке труда. В статье анализируется значимость экономического капитала на рынке высшего образования и социальные последствия выбора "Аоступного" профессионального образования.

К^ючевые слова: высшее образование, доступность образования, экономические барьеры, семьи с высоким уровнем дохода, семьи с низким уровнем дохода, ресурсный потенциал семьи.

\section{Introduction}

Modern trends in Kazakhstan's higher education. The collapse of the Soviet Union had a strong impact on the higher education system in Central Asia, which was highly centralized in the territory of Soviet Union. Higher Education of the Central Asian countries is developing under the influence of the Soviet legacy and international challenges at the same time, thereby forming a "hybrid" structure and content. In Kazakhstan reforms aimed at ensuring the integration of Kazakhstani higher education in the European area are intensively carried out. However, borrowing of European standards has complicated the internal substantial system of university education. At this time new opportunities are developing, and old ones are rapidly declining.

Economic accessibility of higher education for families is defined by two parameters: the possibility of paying tuition fee and the possibility of using paid forms of preparation for receiving the state grant. In order to ensure equal access of all groups of population to higher education the country has established a unified approach to the formation of the student contingent of universities. Every year, the government provides grant funding for higher education. Admission to universities is implemented on a competitive basis through test examination. But here also exist economic barriers for obtaining state grants for tuition fee free education. Preparatory race exhausts family budgets. In this aspect, highincome families have more opportunities to pay for private tutoring of their children for preparation for the test. This greatly increases their chances to study for free.

\section{Main body}

Economic barriers and higher education. The interrelation of educational choice of the child with economic capital of the family is determined by numerous studies. This interrelation manifests itself in different ways:

- Firstly, Raymond Boudon distinguishes primary and secondary effects of the economic capital of the family in education. The primary effects are determined by the influence of the economic capital of a family on academic success of children (Goldthorpe, 1996). Children from higher-income families study better than their peers from low income families. Since wealthy families provide their children with the best conditions for mental development (Dhesi, 2001:16). As a result, high academic results determine their further more ambitious educational choice (Werfhorst, 2009). A secondary effect is determined by the influence of the economic capital of a family on the educational choice of children regardless of their academic success. Even if children have the same performance, a child from a high-income families is committed to a higher level of education than a child from a lower-income families (Erikson, 2007).

- Secondly, families with different economic capital differently assess similar costs, expenses and the risks of educational choices of their children (Konstantinovskiy, 2012). It is these differences that become a source of inequality in education (Boudon, 1973). Economic capital allows families to "invest" in the education of children (Hansen, 2008; Harper, 2007), as well as to expand opportunities for children to choice a desired professional education (Bourdieu 1966: 325). High-income parents can provide their children a quality education, which in turn allows 
them to occupy higher social position in the future (Tzanakis, 2011).

- Thirdly, for children from high-income families receiving a quality higher education is often a way of preserving the social status of the family (Stocké, 2007). Through the leverage of education parents pass their social position and status to children (Blau, 1967). Thus, education contributes to the preservation of the social order in society (Bourdieu, 1970).

- Fourth, the cultural capital, especially starter, being the most "hidden" and socially the most significant one, mainly is inherited by family or in the term of Bourdieu is manifested through the family "habitus" (Halsey, 1993). Cultural practices of high-income families contribute the conservation of requests for higher education (Lamont, 1988). The theory of cultural capital determines the importance of socialization through cultural practices, such as an interest in art and classical music, visiting theaters and museums, reading books. According to the theory, children who are not familiar with this type of socialization will consider the school as a "hostile" environment. As a consequence, they do not aspire to higher education (own choice), and if they decide to get it, they do not achieve the expected results (indirect exception), or may not be acknowledged by teachers (teacher's choice) (Kalmijn, 1996; Lamont, 1988).

At the core of the construction we have chosen is the model of educational choice including the determinants (personal characteristics of the child and the socio-economic, cultural capital of the parents) and dependent factors (choice of education level, profession and educational institution) (Reay, 2001).

Methodology. The article presents the results of two research measurements - a survey of students, interviews with school graduates and their parents.

The survey covered 1,600 students from the cities of Nur-Sultan, Almaty and five regions of Kazakhstan (Eastern, Southern, Western, Northern and Central regions). 27.9\% - 1st year students, $23.4 \%$ - 2nd year students, $24.8 \%-3$ rd year students, and $23.9 \%-4^{\text {th }}$ year students. The gender distribution in the sample was slightly shifted $40 \%$ male and $60 \%$ female. The sample is representative of Kazakhstan student youth by basic socio-demographic characteristics. Research data is processed and analysed with licensed software SPSS for Windows (version 21).

Results of the first research allowed us to understand and determine the factors to be considered in the first place when choosing education, profession and a HEI. Data from this research helped us to form the basic criteria for potential participants of the interview.

We conducted 80 interviews with parents of school-graduates. The interviewees were representatives of different professions, different levels of education, social status and economic well-being.In interviews took part 35 fathers, 36 mothers and 9 interviews were conducted together with both parents. Household composition varied: many children, divorced, single parents, married, including cohabitation and etc. The age span of parents is fairly large - from 32 to 74 . The average age of the parents is 45 years.

Research Ethics Statement. The interviewees were informed about confidentiality of conducted sociological research. The names listed in the article are replaced with analogues. Interviews were conducted in Russian and Kazakh languages according to the request of interviewees.

\section{Results of the research.}

Higher education is becoming the norm, and a necessary condition for life in society. Among parents $-75 \%$, and among children $-91 \%$ believe that higher education is essential to a successful career and implementation of the professional strategy;

Specificity of the Kazakh youth's motivation structure of level of education and profession selection is the fact that in social behavior they are guided not only (and not so much) by personal views, ideas and interests, but are rather under the influence of the values and models of educational and professional comportment prevailing in the surrounding social environment. Almost every third $(30.7 \%)$ young citizen of Kazakhstan is guided by the advice of parents and relatives in choice of a profession. It should be noted that for $28.9 \%$ of young people an important factor in the choice of specialty is its social significance in the development of society.

Access to the "quality, prestigious" education to a large extent is determined not only by the abilities of young people but also by the resource potential of family, which includes the social status, informal ties ("influential ties"), place of residence, and the financial component. The allocated differences in the resource potential of families stipulate significant inequality in access to higher education. Along with the income, social (social status, family ties) and cultural capital (availability of cultural and educational resources) become an important factor in obtaining prestigious education (see Table 1). 
Table 1 - The attitude of youth to the tuition fees of the higher education (in\%)

\begin{tabular}{|c|c|c|c|c|c|c|c|c|}
\hline \multicolumn{3}{|c|}{$\begin{array}{l}\text { Young people from high-income } \\
\text { families }\end{array}$} & \multicolumn{3}{|c|}{$\begin{array}{l}\text { Young people from middle-income } \\
\text { families }\end{array}$} & \multicolumn{3}{|c|}{ Young people from low-income families } \\
\hline $\begin{array}{l}\text { Higher } \\
\text { education } \\
\text { should be } \\
\text { tuition fee } \\
\text { free }\end{array}$ & $\begin{array}{l}\text { Higher } \\
\text { education } \\
\text { should be } \\
\text { paid }\end{array}$ & $\begin{array}{c}\text { Both options } \\
\text { should be } \\
\text { available }\end{array}$ & $\begin{array}{l}\text { Higher } \\
\text { education } \\
\text { should be } \\
\text { tuition fee } \\
\text { free }\end{array}$ & $\begin{array}{c}\text { Higher } \\
\text { education } \\
\text { should be } \\
\text { paid }\end{array}$ & $\begin{array}{c}\text { Both options } \\
\text { should be } \\
\text { available }\end{array}$ & $\begin{array}{l}\text { Higher } \\
\text { education } \\
\text { should be } \\
\text { tuition fee } \\
\text { free }\end{array}$ & $\begin{array}{l}\text { Higher } \\
\text { education } \\
\text { should be } \\
\text { paid }\end{array}$ & $\begin{array}{c}\text { Both } \\
\text { options } \\
\text { should be } \\
\text { available }\end{array}$ \\
\hline $12 \%$ & $67 \%$ & $21 \%$ & $31 \%$ & $35 \%$ & $34 \%$ & $89 \%$ & $1 \%$ & $10 \%$ \\
\hline
\end{tabular}

The vast majority of young people (89\%) of lowincome families said that education at the university must be funded by the state. While this opinion is shared by only $12 \%$ of youth from families with higher income. However, households with lower and middle incomes are guided by the opportunity of receiving a grant, while paying tuition fee is regarded as a back up plan.

Parents' preferences in higher education. In general, awareness of the necessity to pay for education is quite firmly rooted among the population of Kazakhstan. Differences in income significantly affect the differences in access to higher education. But these differences are mainly related to the quality of the education received, and not with the economic conditions of education (tuition fee free or paid). Both families with higher and lower income pay tuition fee at the university. However, families with lower income choose cheaper options for education: less prestigious HEIs and specialties, less costly forms of education. Family income significantly affects the accessibility of higher education and, consequently, the likelihood of enrollment. Income amount around $30000 \mathrm{KZT}$ per one member of the family is significant, with an income of 100000 KZT differences smooth out. In these circumstances, parents whose income is considered to be quite high agreed to pay for the education.

"The very least that our daughter should get is a higher education. Me and my husband have a degree. I believe that quality education is very important. Our daughter is studying in a private school and has a certain knowledge, keeping in mind knowledge of a foreign language, we expect that she will enroll a foreign university. Aizhan (daughter - authors' note) wants to go to Seoul National University, the specialty "medicine". We believe that this profession is in demand in our country and there will be no particular problems with employment. We are ready to pay big money up to $\$ 15000-25000$. We will support our daughter, even till the end of postgraduate education» (interview №10).
"We still can not take a final decision in the choice of the country for education, which is ongoing discussion in the family. We want our son to follow the path of science, and not only got a master degree, but also got his PhD in the future. If we talk about the possible amount of tuition fee, we are willing to pay up to $\$ 12000$. With a choice of a profession we have already decided: the oil and gas or degree in economics. Elnur (son - authors' note) wants to study in Kazakh-British Technical University" (the old name of the university - the authors note) (interview №1).

Our family does not experience financial difficulties. We want Aslan (son - authors' note) most importantly, to get a quality education in a prestigious university, regardless of the tuition fee price. Then we plan to enroll in master degree program. When choosing a HEI, we pay special attention to the prestige of the university, access to quality knowledge. Aslan is interested in the specialty "Law" and he wants to study this specialty. As for now our choice is KIMEP University (interview №4).

"Well-paid job" is the main reason for families with low income to believe that it is necessary for their children to get a higher education. The majority of the assured are those who have "secondary education" $65 \%$ and "vocational education" $-70 \%$. But in view of the limited financial capabilities - range of choice of educational institutions is dramatically narrowed. Most of them agree with the fact that higher education requires material investments. However, they are forced to consider low-cost options, such as college education, or education in less prestigious universities. The reasonable cost of tuition fee is 200000 - $300000 \mathrm{KZT}$. Mostly, parents orient their children to state grants and the choice of future profession is not related to competitive advantage and high motivation of their children.

"We have not decided what university or college will apply to. Of course, it is desirable that our son gets a degree, but if not - we'll see what we do next. 
We will try to apply to college on the basis of the state grant». (Interview №120).

«We think our son will apply to college. The most important thing is to get at least any sort of education, and then we'll see. But our son has a desire to receive a higher education. In the meantime we are trying to explain him that he can continue his education in the future. Aidar (son - the authors' note) wants to study in Kokshetau Technical Institute of the Committee for Emergency Situations of the Ministry of Internal Affairs of the Republic of Kazakhstan, and to get specialty "Lifesaver" (interview №72).

It is desirable that our son gets a bachelor degree, however we are not considering postgraduate education (master degree). We've chosen the direction "Ecology", with the exact specialty have not decided yet. Looked through the scores on last year's national competition, we've noted that in this area competition is not so high that increases our chances of getting the state grant. Timur (son - the authors' note) wishes to study in the Kazakh National Agrarian University (interview №66).

High-income families are ready to "invest" in their child's education; they are characterized by a strong commitment to post-graduate education (Master and $\mathrm{PhD}$ programs). They begin to "invest" in their children's education from an early age: children study in good private schools. Consequently, they have formed a high start-up capital, which gives them the opportunity to make ambitious educational plans and increases the competitiveness on the education market. Foreign language proficiency and economical capital of family permits to school graduates to study abroad. Graduates of the big cities of high-income families showed a strong desire to study in foreign universities.

Our daughter wants to get a degree in "Engineering". We plan to apply to the Technical University of Vienna. Aloi (daughter - authors' note) has made decision on her own, we fully agree with it. In the future she will be able to earn good money and will have the opportunity for career growth. Particular attention is paid to the authority of the university, the position in the world rankings of universities, the prestige of the chosen specialty. We do not suffer financial difficulties and we can pay up to $\$ 45000$. Aloi studies in a private school, she has a very high intellectual potential, has a very good in English. Having graduation we plan to get M.A. (interview №11).

We want our son to receive a high quality education. After graduating, we plan to continue education and to receive a master degree and then enroll in a doctorate program. We are willing to pay to $\$ 30000$. We think to study in a foreign university, but firstly Alibek (son - authors' note) will have a six-month internship at Lancaster University. And then we'll see ... Alibek is fluent in English and knows German (interview №12).

The choice of HEI. According to a survey of young people in selecting a HEI the top three most important critera include: 1) prospects of getting a high-quality education $(97.7 \%), 2$ ) low tuition fees and opportunities for tuition fee-free education $(87.1 \%), 3)$ the prestige and rankings of HEI $(83.7 \%)$. The first criterion - opportunities of obtaining a quality education is essential for the majority of young people from wealthier families $(99.9 \%)$ in the evaluation and selection of the university. This criterion is also important for young people from low-income families, but to a less extent than for the youth form higher-income families and equals $81 \%$. It is indicative that high-quality education in the public opinion of young kazakhs is projected by a certain university and its "brand."

High orientations to receive the state grant, which provides tuition fee free education are characteristic not only of young people from lowincome families $(80 \%)$, but also for young people from high-income families $(85 \%)$. Competition for educational grants requires a strong starter educational capital to obtain high results in the entrance exams. Differences between knowledge required to succesfully pass the test and school knowledge, determined active development of paid services to prepare for the entrance exams. In this aspect, low income of families becomes a barrier to admission to HEIs. Since preparatory race (private tutor services, additional courses and etc.). exhausts family budgets. For example, the price of one hour of private tutoring in the regions and cities of research varied from 2,000 to 5,000 tenge. The third criterion - the importance of prestige and rankings of HEI is equally important for young people from both low-income and high-income families.

\section{Conclusion}

As shown by our research, orientation on higher education differs in the degree of future students' motivation and their readiness to overcome the threshold to enter the higher education system. Contingents of applicants for higher education have different starting opportunities (family income), social and cultural capital. Access to higher education is assessed controversially by both parents and their children and is dependent on the resource characteristics of households (social 
status, material status, place of residence etc.). The choice of future profession of school graduate is not a mechanical process, but a significant number of young people exposed to the influence of parents, relatives and friends, follow stereotypes and avoid responsibility.

The higher the level of education and cultural capital of the parents, the greater strength in the minds of children takes the value of education and the high motivation of receiving it. Transition to Unified Test, increases motives for schools graduates to use the services of private tutors, thus limiting the accessibility for higher education among graduates of rural schools. However, the majority of educational institutions located in rural areas and small towns are not included in pre-university preparatory network or included in the worst conditions compared with schools in the HEI centers. In recent years, the situation began to improve due to the fact that the state has developed a mechanism for providing quota places for rural graduates.

\section{References}

Goldthorpe J. (1996) Class Analysis and the Reorientation of Class Theory: The Case of Persisting Differentials in Educational Attainment. British Journal of Sociology, 47(3), pp. 481-505.

Dhesi A. (2001) Expectations and post-school choice: some data from India. Education Training, 43(1), pp.14-24.

Van de Werfhorst, Herman G. (2009) Education, inequality, and active citizenship. Tensions in a differentiated schooling system. Working paper, $59 \mathrm{p}$.

Erikson R. J., Goldthorpe M., Jackson M., Yaish D. (2005) On Class Differentials in Educational Attainment. Proceedings of the National Academy of Sciences, Vol. 3(8), 102(27), pp. 9730-9833.

Konstantinovskiy D. (2012) Social Inequality and Access to Higher Education in Russia. European Journal of Education, Vol. 47(1), pp. 9-24.

Boudon R. (1973) L’inégalité des chances, La mobilité sociale dans les sociétés industrielles. Paris: Colin, 237 p.

Tzanakis M. (2011) Bourdieu's social reproduction thesis and the role of cultural capital in educational attainment: a critical review of key empirical studies. The journal of doctoral research in education, Vol. 11(1), pp. 76-90.

Stocké V. (2007) Explaining Educational Decision and Effects of Families' Social Class Position: An Empirical Test of the Breen-Goldthorpe Model of Educational Attainment. European Sociological Review, Vol. 23 (4), pp. 505-519.

Blau P., O. Duncan. (1967) The American occupational structure. N.Y.: John Wiley and Sons, 520 p.

Bourdieu P., Passeron J. (1970) La reproduction. Eléments pourune théorie du système d'enseignement. Paris: Editions de Minuit, $280 \mathrm{p}$.

Halsey H. (1993) Trends in Access and Equity in Higher Education: Britain in international perspective. Oxford Review of Education, 19:2, pp. 129-140.

Michele L., Lareau A. (1988) Cultural Capital: Allusions, Gaps and Glissandos in Recent Theoretical Developments. Sociological Theory, Vol. 6, pp.153-168.

Kalmijn A., Matthijs M., Kraaykamp G. (1996) Race, Cultural Capital, and Schooling: An Analysis of Trends in the United States. Sociology of Education, Vol. 69, pp. 22-34.

Lamont M., Lareau A. (1988) Cultural Capital: Allusions, Gaps and Glissandos in Recent Theoretical Developments. Sociological Theory, Vol.6, pp.153-168.

Reay D., Davies J., David M., Ball S.J. (2001) Choices of Degree or Degrees of Choice? Class, Race and the Higher Education Choice Process Sociology, Vol. 35, no 4, pp. 855-874. 